\title{
Entrepreneurship Education and Sustainability Economic in Nigeria
}

\author{
Dr Ogunmola, M.O. ${ }^{1} \quad$ Olayemi, A.E. ${ }^{2}$ \\ 1.Department of Fine and Applied Arts, College of Education, Ikere Ekiti, Ekiti State, Nigeria \\ 2.Department of Business Education, School of Vocational and Technical Education, College of Education, \\ Ikere Ekiti, Ekiti State, Nigeria
}

\begin{abstract}
Entrepreneurial education as the blood that running sustainable development in Nigeria economy. The problem facing Nigeria right from independence are high rate of poverty, graduate unemployment, overdependence in foreign goods and poor technological for growth and development. This paper argued that, Entrepreneurship education will equip industrial with skill to be self-reliance. Some theories of entrepreneurial education and development are highly considered, while challenge of entrepreneurial education and their way out are highlighted. It was recommended that effective technical education and youth empowerment programme should put in place in every knock and crannies of the country for proper development. It was also recommend that educational programme at all level should be made relevant and if necessary should be compulsory and free to all youths so that the attention will be shifted away from white collar job. The government should give adequate attention to entrepreneurial development in the country through the provision of goods economic environment. If done, it will enhance job creative, vocational skill, employment opportunities and reduce poverty in society.
\end{abstract}

Keywords: Entrepreneurship, Education, Sustainable, Economy Development, Training, Government.

DOI: $10.7176 / \mathrm{RHSS} / 10-2-02$

Publication date: January $31^{\text {st }} 2020$

\section{Introduction}

Accordingly, poverty eradication and employment generation have been top priorities of many government and institutions in developing countries (MDGs report in Garba, 2010). These problems appear to be getting worse by the day as hundreds of thousands of graduates are churned out annually from the various Nigerian institutions of higher learning. As if to compound the problem, there appears to be a disconnect between the various theoretical knowledge accumulated in school and the practical realities of such knowledge. This paper addresses the need for proper tailoring of Nigerian education system towards a sustainable entrepreneurship development.

This paper does this under the following subheading: introduction, meaning of entrepreneurship and entrepreneurial education with its objectives, history of entrepreneurship in relation to Nigeria, educational policy and entrepreneurship, various theories of entrepreneurship, entrepreneurship development efforts in Nigeria, examination of challenges and possible solutions to entrepreneurship education and development policy implication, recommendations and conclusion. Entrepreneurship started to gain ground in Nigeria as a result of level of unemployment that floor our employment market. Nigeria stated witnessed unemployment in early eighties during civilian region of late president, Alhaji Sheu Shagari of bless memory.

Economic development through entrepreneurial education has become a major concern of all well-meaning countries of the world. There are a number of programmes and policies tailored towards the development of entrepreneurial mind-set among people from all walks of life in these countries. These programmes include both structured and unstructured ones. Entrepreneurship is becoming a focal point for the various economies of the world as a result of its potency to greatly influence economic growth and development through entrepreneurial drive and persistence (Kuratko, 2009).

The recent effort of the federal government of Nigeria in floating the youth empowerment and social support operation-YESSCO- through National Directorate of employment (NDE) as a project for rescuing our youth in a right step to the right direction. Nigeria cannot sit back and watch other nations make progress in the common quest for economic independence; being able to deal with the problem of unemployment, poverty and other related socio-economic challenges. The fact that Nigeria has remained a developing economy for this long has even made urgent, the need to fully embrace the 'letter and spirit' of entrepreneurship by all individuals and institutions.

\section{Entrepreneurship Definition}

Entrepreneurship education are increasingly recognized an important achieve of economic growth, productivity and employment and as a key aspect of economic dynamic. Government policies on entrepreneurship education ethical for ensuring what entrepreneurship is embedded into the formal educational system, and offered through partnership with the private sector, the informal community, and rural and apprentice training programme.

Entrepreneurship has been defined variously by different authors. The concept is seen as the dynamic process of creating wealth by individuals who assume the risks involved in providing value for some products and/or 
services (Kuratko, 2009); "the process of performing the roles of planning, operating and assuming the risk of a business venture," (Inegbenebor \& Igbinomwanhia, 2010); "the pursuit of lucrative opportunities by enterprising individuals...(being) inherently about innovation - creating a new venture where one didn't exist before," (Bateman $\&$ Snell, 2011); the process of creating value through the provision of some products or services for the benefit of the society, while learning the skills needed to assume the risk of establishing a business Ahiauzu, 2009; Inegbenebor, 2006).

One of the key success factors for entrepreneurship education is effective development of the entrepreneurial ecosystem, in which multiple stakeholders plays a role in facilitating entrepreneurship. it is a system of mutually beneficial and self-sustaining relationships together with the grail of creating entrepreneurial ventures.

According to Brown (2000), entrepreneurial education is designed to communicate and inculcate competencies, skills and values needed to recognize business opportunity, organize and start new business venture.

The role of government is crucial in creating the proper regulatory framework and incentives to catalyse this involvement of the private sector, education institutions, individual and intermediaries within an entrepreneurial ecosystem. However, in many development countries, each of these groups of actors may be at an early stage of development in terms of entrepreneurship, or perhaps not yet focused on it due to other priorities and the allocation of seared resources.

\section{Objective of Entrepreneurship Education}

According to Adesulu (2010), to achieve vision, 20:2020 objective, we must not only teach entrepreneurship in our schools, we should also be ready to practice entrepreneurs. However, the operational definition of entrepreneurship education is the willingness and ability of a person on person to acquires the educational skills to explore and exploit investment opportunities establish and manage successful business enterprise Entrepreneurship education according to Egunjimi (2012), is a structured to achieved the following objective:

- To offer functional education for the youth that will enable them to be self- reliant

- To provide the youth granites with equate training that will enable them to be creative and innovative in identifying novel business opportunities

- To sever as a catalyst economic growth and development

- Offer tertiary institution graduates with adequate training in risk management and to make curtain bearing feasible

- To reduce high rate of poverty

- To create employment generation

- $\quad$ Reduce in rural urban migration

- Provide the young graduates with enough training and support that will enable them to establish a career in small and medium sized business

- To inculcate the spirit of perseverance the youths and adults which will enable to persist in any business venture embark on,

- Create smooth transition from traditional to modern transition economy.

\section{Needs for Entrepreneurship Education}

Entrepreneurship education seeks to prepare people, especially youth, to be responsible, enterprising individuals who become entrepreneurs and who contribute to economic development and sustainable communities. Entrepreneurship education is not based on a textbook course and is needed for the following reasons:

To raise students that are immersed in real-life learning experiences where they have an opportunity to take risks, manage the results and learn from the outcomes. Entrepreneurship education encourages creative thinking and promoting a strong sense of self-worth and accountability. It also teaches someone how to run business.

Through entrepreneurship education, students learn how to create a business but they also learn a lot of things. The core knowledge created via entrepreneurship education includes:

- The ability to recognize opportunities in one's life.

- The ability to pursue such opportunities by generating new ideas and marshalling out needed resources.

- The ability to create and operate a new venture.

- The ability to think in a creative and critical manner.

It provides all age levels training in all vocational education programmes. Entrepreneurship courses and programmes have suffered through differing philosophies of senior officers in Nigerian universities. While we cannot put an artificial freeze on these positions, we can move the entrepreneurship field into a leadership role at the institutions. It is hard for any senior officer to ignore a programme that stands in a leadership and influential position among students, business leaders, donors and other faculty. 


\section{Entrepreneurship Development in Nigeria}

Entrepreneurial development may be conceived as a programme of activities to enhance the knowledge, skills, behaviours and attitudes of individuals and groups to assume the role of entrepreneurs as well as efforts to remove all forms of barriers in the path of entrepreneurs. It is anchored on the firm belief that entrepreneurship involves a body of knowledge, skills and attitudes which can be learned and applied by most people who are sufficiently motivated. In contrast to the idea that entrepreneurs are born, entrepreneurship development recognises that many individuals have latent potential to fit into the role of entrepreneurs. Such potentials can be actualised through training programme (Inegbenebor, 1999). Entrepreneurship development assumes that through the process of learning, these characteristics or pattern can be acquired by anyone who is adequately motivated. Similarly, individuals can learn to deal with socio-cultural constraints and inhibitions prevalent in growing economies. Entrepreneurs can be trained also on how to establish and maintain effective relationship with financial institutions, suppliers, government agencies, and other critical institutions upon which they depend for information, guidance and inputs. It is possible to achieve all these through business counselling and by providing relevant information (Inegbenebor, 1999).

\section{The Roles of Entrepreneurship Education as the means of development in Nigeria Economy}

The concept of sustainable economy requires upholding the circulation of money and economic considerations in the pursuit of an improved standard of living and poverty alleviation. Sustainability includes intergenerational equity, just and peaceful societies, social tolerance, environmental preservation and restoration, poverty alleviation and natural resource conservation. The major essential tools for achieving sustainable economy include the following areas:

- Improve the quality of basic education.

- Reorient existing education programmes to address sustainable economy.

- Implementing various poverty alleviation programmes

- Rural electrification

- Developing employment generation and enhancing agricultural output and income.

The Nigerian government seems to have woken up to the reality that the country needs to break away from the vicious cycle of poverty, infrastructural neglect, corruption and other social problems. The reason being that, after 52years of achieving colonial independence, it cannot be argued that Nigeria has attained her optimum level of economic development. According to Kolawole and Omolayo (2006), many individuals have difficulties in translating their business ideas to realities and creating new business ventures because of lack of necessary information and skills needed to achieve their targets. To them, the school curriculum was in the past oriented towards making graduates suitable only for white-collar jobs. This underscores why millions of our youths and a lot of university graduates roam the streets of the major cities and towns in search of white collar jobs.

For many developing countries, entrepreneurship has been a powerful engine of economic growth and wealth creation, and is crucial for improving the quality, number and variety of employment opportunities for the poor. It has several multiplier effects on the economy, spurs innovation, and fosters investment in people, which is a better source of competitive advantage than other natural resources, which can be depleted. Entrepreneurs create new enterprises, new commercial activities, and new economic sectors. They generate jobs for others; they produce goods and services for society: they introduce new technologies and improve or lower cost outputs; and they earn foreign exchange through export expansion or the substitution of imports. Entrepreneurial activities, if properly carried out and supported by active government policies and infrastructures has the capacity to bring Nigeria out of its current levels of poverty; currently having over $10 \%$ of her population living under \$2 (two dollars) a day and 54\% living under $\$ 1$ a day. Even with the presence of white collar jobs for graduates who want to pursue professional careers, it is also expedient to acquire entrepreneurial skills. This serves as a means to the end of generating extra income for self sustenance.

\section{Benefits of Entrepreneurship Education to Nigeria Economy}

- Provision of employment opportunities: Entrepreneurial activities boost employment opportunities. Businesses need people to work for them. Entrepreneurship also reduces the number of job seekers on the streets searching for jobs that are not available. Unemployment and idleness are also responsible for the high rates of crime and violence on the streets and among youths.

- Effective resource utilization: Entrepreneurship utilizes natural resources, thereby engaging resources from less productive to more productive areas, hence increasing value to both the entrepreneur and the economy as a whole. Nigeria's vast natural and human resources are utilized effectively.

- Equitable distribution of income and wealth: With more entrepreneurial activities provided in the rural areas, more wealth is created thereby propagating the economic progress of both the communities and its individuals. Thus more villagers have more work opportunities, hence reducing the rate of rural to urban migration. Entrepreneurial activities in the rural areas create new jobs thereby increasing local incomes, and 
improving the quality of life in the rural communities. Such entrepreneurial activities effectively connect the rural communities to the larger urban communities.

\section{Conclusion and Recommendations}

Embarking in entrepreneurial activity is an important tool of attaining sustainable economic development. Entrepreneurship also provides an opportunity for a person to improve quality of life and make contributions to society. Acquisition of entrepreneurial skill is a way of empowering the youth to have confidence in their ability to add to the productivity level envisaged for a sustainable economy. It is concluded that improved and sustainable global economy depends on a strong entrepreneurship education. It is against this background that the following recommendations are proffered for effective entrepreneurship education in Nigeria:

- Entrepreneurship behaviours can be developed, practiced and learned therefore, it is important to expose all students to entrepreneurial education.

- Nigerian government should promote entrepreneurship education through appropriate policy.

- Entrepreneurship education should re started as early as primary school and progress through all levels of schooling to further inculcate and develop entrepreneurial skills in young people.

- The National Universities Commission (NUC) should lay more emphasis on the creation of entrepreneurship development centre where at least two compulsory courses on entrepreneurship will be offered by all undergraduate students' irrespective of their discipline in Nigerian universities. The same thing should be done for the Polytechnics and Colleges of Education.

\section{References}

Abdullahi.S- A. (2009). Entrepreneurship skills development as an economic empowerment and poverty reduction strategy in Nigeria. Nigerian Academy of Management Journal, 3(1), 46-65.

Adesulu. D. F. (2010). Entrepreneurs-hip Education Only Way to Achieve Vision 20:2020.Vanguard News paper. Thursday, 25th March.

Ahiauzu. A. (2009). Entrepreneurship and economic development in Nigeria: The way forward. Nigerian Academy of Management Journal, 3(1), 1-18.

Bateman. T. S., \& Snell, S. A. (2011). Management: Leading and Collaborating in the Competitive World ( $9^{\text {th }}$ Edition). New York: McGraw-Hill, Irwin Companies, Inc

Brown.C. (2000).Entrepreneurship education teaching guide. Kansas City: Kauffman Centre for Entrepreneurial leadership Clearing House on Entrepreneurship Education.

Egunjirni. F.H (2012) Entrepreneurship Education: A tool for national economy in Nigeria a seminar paper presented at University of Ilorin. Nigeria. $16^{\text {th }}$ April. 2012

Garba. A.S. (2010). Refocusing education system towards entrepreneurship development in Nigeria: A toll for poverty eradication. European Journal of Social Sciences, 15(I), 140-150.

Inegbenebor, A. U. (1999). Selected readings in entrepreneurship. Unpublished lecture note. Department of Business Administration, University of Benin, Benin City.

Inegbenebor, A. U. (2006). Education for entrepreneurship: Experience of the University of Benin, Benin City, Nigeria. Nigerian Academy of Management Journal.

Inegbenebor, A.U. (2012). Entrepreneurship development as a strategy for enhancing private sector led growth in Nigeria. Unpublished manuscript. University of Benin, Benin City.

Inegbenebor, A.U. (Ed). (2006). You can be an entrepreneur. In The fundamentals of entrepreneurship (Pp. 1-14). Lagos: Malthouse Press Limited.

Inegbenebor, A.U., \&Igbinomwanhia, O.R. (2010).Entrepreneurship in a developing society.In F.C. Okafor, P.A, Isenmila, A.U. Inegbenebor and P.A. Donwa (Eds.), Entrepreneurship: A practical approach (Pp. 1-10). Benin City: Mindex Publishing Co. Ltd.

Izedonmi, P. F., \& Okafor, C. (2010).The effect of entrepreneurship education on students' intentions. Global Journal of Management and Business Research, 10(6), 49-60

Kuratko, P. (2009). Some research perspectives on entrepreneurship education, enterprise education and education for small business management: A ten-year literature review. International Small Business Journal, 75(3).

Mandara, B. M. (2012). Entrepreneurship education: A panacea to economic development. Journal of Business and Organizational Development, Vol. 4

Okhakhu, C.O., \& Adekunle, S. A. (2012).Entrepreneurship education and development. Unpublished M.Sc Seminar Paper. Department of Business Administration, University of Benin, Benin City. 